J. Perinat. Med.

2 (1974) 208

\section{Routine diagnosis of fetal lung maturity*}

\author{
Geno Kynast, Erich Saling \\ Unit of Perinatal Medicine - The Free University of Berlin \\ Department of Obstetrics and Gynecology, Berlin-Neukölln
}

Received January 17, 1974. Accepted April 23, 1974.
The respiratory distress syndrome (RDS) is the most frequent postnatal complication of prematurity having a $25 \%$ lethal outcome even today (KeUth [6]). The same author reports that RDS affects $8 \%$ of an unselected population of premature infants and $20 \%$ of a negatively selected population found in clinical departments for premature babies. Hence avoidance of prematurity is one of the most important tasks of modern perinatal medicine [12]. In those cases in which prematurity is unavoidable, the methods of assessing the maturity of the lungs are becoming more and more numerous [5], e. g. by determining the lecithins content of the amniotic fluid. Our recent investigations show that there is a positive correlation between the lecithins content of tracheal secretion and that of the amniotic fluid [4]. Different authors have put forward methods for determining lung maturity that are of variable effectiveness (for review see [7]). The work presented here suggests practical procedures for the routine diagnosis of lung maturity which can be used to evaluate a decrease in lecithins content in amniotic fluid and relate it to respiratory disturbances.

\section{Method and material}

Good results are obtained with quantitative thin layer chromatography and direct densitometry [7]. Although this densitometric procedure requires less effort than other methods of comparable specificity, the time necessary for routine diagnosis of lung maturity is considerable. Hence a screening procedure has been proposed to eliminate nonaffected cases. The foam test suggested by CLEMENTS et al. [2] is such a qualitative test in which the content of surface active substances is estimated in various dilutions of amniotic fluid from the foam formed after shaking. In suspect cases the lecithins content is then determined densitometrically against a lecithins standard, and the content is calculated by a computer program. This mathematical procedure which decreases the work considerably and eliminates various sources of error has already been published [7]**.

At the start of this work, the same method served to examine the foam test as a screening procedure. For this purpose, 180 samples of amniotic fluid from 165 patients were examined and compared. From this a routine procédure for prenatal diagnosis of lung maturity was developed and applied to 400 amniotic fluid samples from 360 patients. Our densitometric procedure [7] was improved during this time as follows:

1. Time was reduced by heating the thin layer plates during application to $80^{\circ} \mathrm{C}$ instead of $70^{\circ} \mathrm{C}$.

2. The distance to which the chromatogram was run was cut from 10 to $9 \mathrm{~cm}$.

3. A new stable stain was chosen: The plates are still developed in iodine vapors but are then lightly sprayed with the Folin-Crocalteus rea-

* Part of this paper was given as a lecture on the 6 th German Congress for Perinatal MedicineBerlin, Nov.1973.

** A detailed description of the densitometric procedure together with its evaluation and with calculated examples can be obtained from the authors. 
gent (Mcrck No. 9001). The blue-grey spots are then evaluated at $560 \mathrm{~nm}$ at a monochromator aperture of $0.4 \mathrm{~mm}$.

\section{Results and discussion}

Our clinical experience allows us to group the lecithins values in an evaluation scheme as shown in Tab. I.

Tab. I. An evaluation scheme for the determination of fetal lung maturity according to the lecithins content of amniotic fluid.

\begin{tabular}{|c|c|c|}
\hline critical & $\begin{aligned}> & 20.0 \\
& 5.1-20.0 \\
& 3.1-5.0\end{aligned}$ & $\begin{array}{l}\mathrm{mg} / 100 \mathrm{ml}=\text { very good } \\
\mathrm{mg} / 100 \mathrm{ml}=\text { good } \\
\mathrm{mg} / 100 \mathrm{ml}=\text { still normal }\end{array}$ \\
\hline limit & $\begin{array}{l}2.0-3.0 \\
<2.0\end{array}$ & $\begin{aligned} \mathrm{mg} / 100 \mathrm{ml}= & \text { critical } \\
\mathrm{mg} / 100 \mathrm{ml}= & \text { probably } \\
& \text { fetal lung im- } \\
& \text { maturity }\end{aligned}$ \\
\hline
\end{tabular}

\subsection{Assessment of CLEMENTS' foam test}

Fig. 1 shows the relationship between the lecithins content of amniotic fluid and the results of the foam test for samples not contaminated with blood or meconium. A point system is used for the foam test. Each tube in the dilution series according to CLEMENTS et al. [2] showing a closed foam ring is awarded one point, each tube with a partial foam ring half a point and each tube without foam 0 points. Since there are 5 dilutions the test can have 0 to 5 points. This is shown in the following example:

\begin{tabular}{l|c|c|c|c|c|}
\hline tube No.: & 1 & 2 & 3 & 4 & 5 \\
\hline judgement: & + & + & $(+)$ & - & - \\
\hline
\end{tabular}

$+=$ closed foam ring $=1.0$ points

$(+)=$ broken foam ring $=0.5$ points

$-=$ no foam ring $=0$ points

Points evaluation: $1.0+1.0+0.5=2.5$ points

Thus this amniotic fluid would be above the critical limit of 1.5 points, and lung maturity would be considered to be sufficient.

By separately examining amniotic fluid samples showing a closed ring in the first tube and samples showing a broken ring in the first tube, it could be shown that this point evaluation is justified. It was found that all samples containing less than $3.0 \mathrm{mg} / 100 \mathrm{ml}$ of lecithins had a

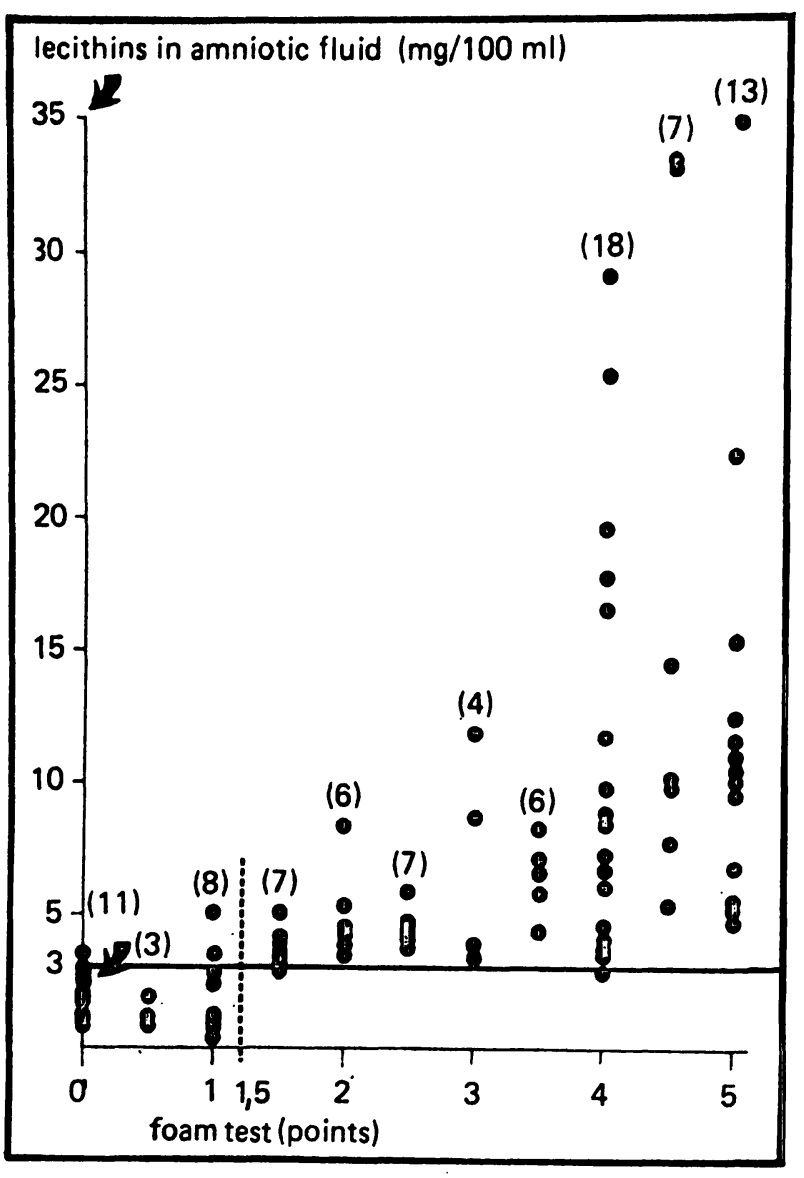

Fig. 1. Comparison of foam test and densitometric determination of lecithins in amniotic fluid samples nor contaminated with blood or meconium.

lower point value than 1.5 , i. e. they lie within the critical RDS-suspect range and could hence be separated out. However, a number of false negative results was also obtained as previously noted by others $[1,3,10]$.

Fig. 2 shows the same results for amniotic fluid contaminated with blood or meconium. Here, not all suspect samples show less than 1.5 points. Hence the foam test cannot be used, as already stated by other authors [2]. Thus we may conclude that the foam test is suitable for amniotic fluid not contaminated with blood or meconium, but without further assessments it cannot be recommended without restrictions.

It should be added that the number of false negative results with the foam test can reach far above the $30 \%$ mentioned in the literature [11] if the working procedure is not strictly followed [2]. It is particularly important to maintain the water content of the ethylalcohol at exactly $95 \%$. 


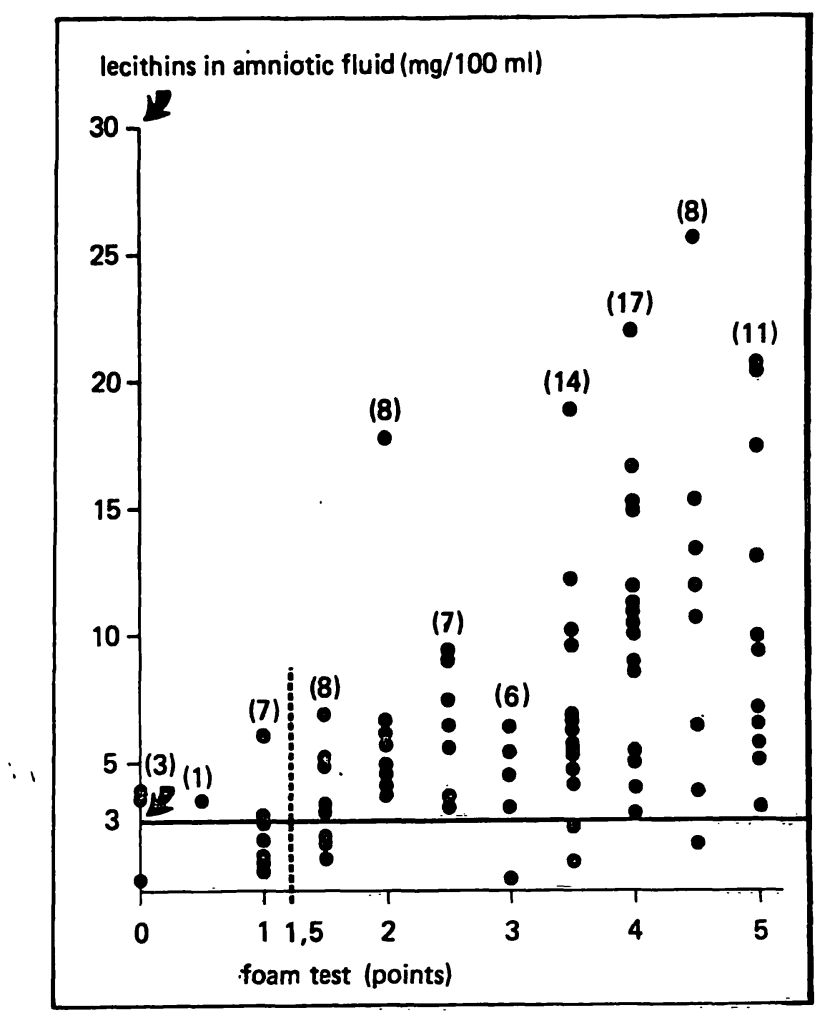

Fig. 2. Comparison of foam test and densitometric determination of lecithins in samples contaminated with blood or meconium.

\subsection{Routine procedure}

A routine procedure, shown in Fig. 3, was developed based on our results.

First, amniotic fluid samples free from blocd and meconium are tested using the foam test. Samples with more than 1.5 points are considered normal.
All samples contaminated with traces of blood or meconium are examined densitometrically. If more blood is present, the sample is discarded. Samples containing more than $3.0 \mathrm{mg}$ lecithins per $100 \mathrm{ml}$ are considered normal. All samples with lower values are judged as critical or suspect, indicating lung immaturity.

\subsection{Clinical examples and findings}

In patients selected using the above procedure, further amniocenteses were performed at 3- and in isolated cases at 1- to 2-day intervals until the lecithins content exceeded the critical limit of $3.0 \mathrm{mg} / 100 \mathrm{ml}$. Fig. 4 shows for example a few cases in which a lecithin deficit was found early enough to delay labor until the lungs have matured sufficiently. Line 9 represents a special case of malformation with lung hypoplasia. The low lecithins content in the amniotic fluid confirms that normal values are not obtained if the lung, the producer of lecithins, is affected and that other possible sources, e. g. the membranes, probably contribute only few lecithins. It is noteworthy that 6 of the 10 cases $[4-8,10]$ were dysmature. This important finding, i. e. a relationship between dysmaturity and lowered lecithins values, will be reported elsewhere [8].

In 5 of the 10 cases $[1-3,7,9]$ an attempt was made to delay imminent premature labor by administering tocolytics for several weeks ( $T h$ 1165a/BOEHRINGER, Ingelheim). It is apparent

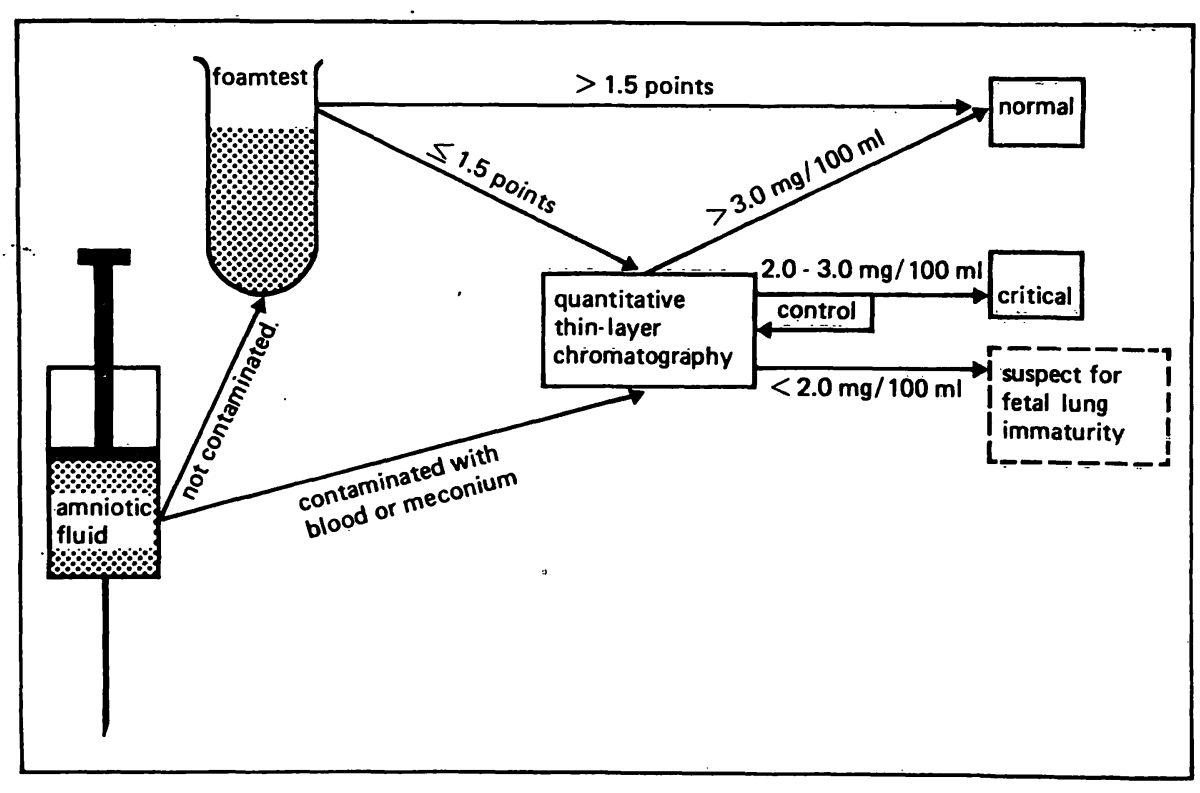

Fig. 3. Routine procedure for the diagnosis of fetal lung maturity. 
that this measure has no positive effect on the lecithins content.

In several further cases with lecithins deficit, corticoid therapy according to Liggins and HowIE [9] was used. Results will be presented later.

Fig. 4. Lecithins content in amniotic fluid of endangered fetuses 1: severe RDS (35th week), 2: latent diabetes (38th week), 3: died of RDS (36th week), 4: dysmaturity (40th week), 5: dysmaturity (38th week), 6: dysmaturity (36th week), 7: slight dysmaturity (36th week), 8: gestosis, dysmaturity and prematurity, slight RDS (37th week), 9: malformation, lung hypoplasia, unilateral bronchial atresia, RDS, died after delivery (37th week), 10: dysmaturity (40th week).

In cases $1-3,7$ and 9 tocolytic drugs were administered.

\section{Summary}

A densitometric procedure for determining the lecithins content of amniotic fluid and its computerized evaluation is described for routine diagnosis of lung maturity in risk pregnancies. Densitometry was improved compared to the earlier method [7], including a new stain for the TLC plates. The foam test of Ciements [2] was used for screening to facilitate the procedure. It had first been tested in 180 pregnancies, showing it to be unsuitable for amniotic fluid samples contaminated with blood or meconium. As an exclusive test its value is limited. A procedure was then elaborated (Fig. 3) which selects all cases below the critical limit of $3.0 \mathrm{mg}$ lecithins $/ 100 \mathrm{ml}$ amniotic

Keywords: Amniotic fluid, lecithins, respiratory distress syndrome, foam test.

\section{Zusammenfassung}

Es wird über ein Verfahren berichtet, das die routinemäßige Kontrolle der Lungenreife gefährdeter Schwangerschaften auf dem Wege über densitometrische Lezithinbestimmungen im Fruchtwasser mit Auswertung durch einen Kleinrechner ermöglicht. Die Densitometrie wurde dabei in verschiedenen Punkten im Verglcich zum früher beschriebenen Verfahren [7] verbessert, wobei die Ån-

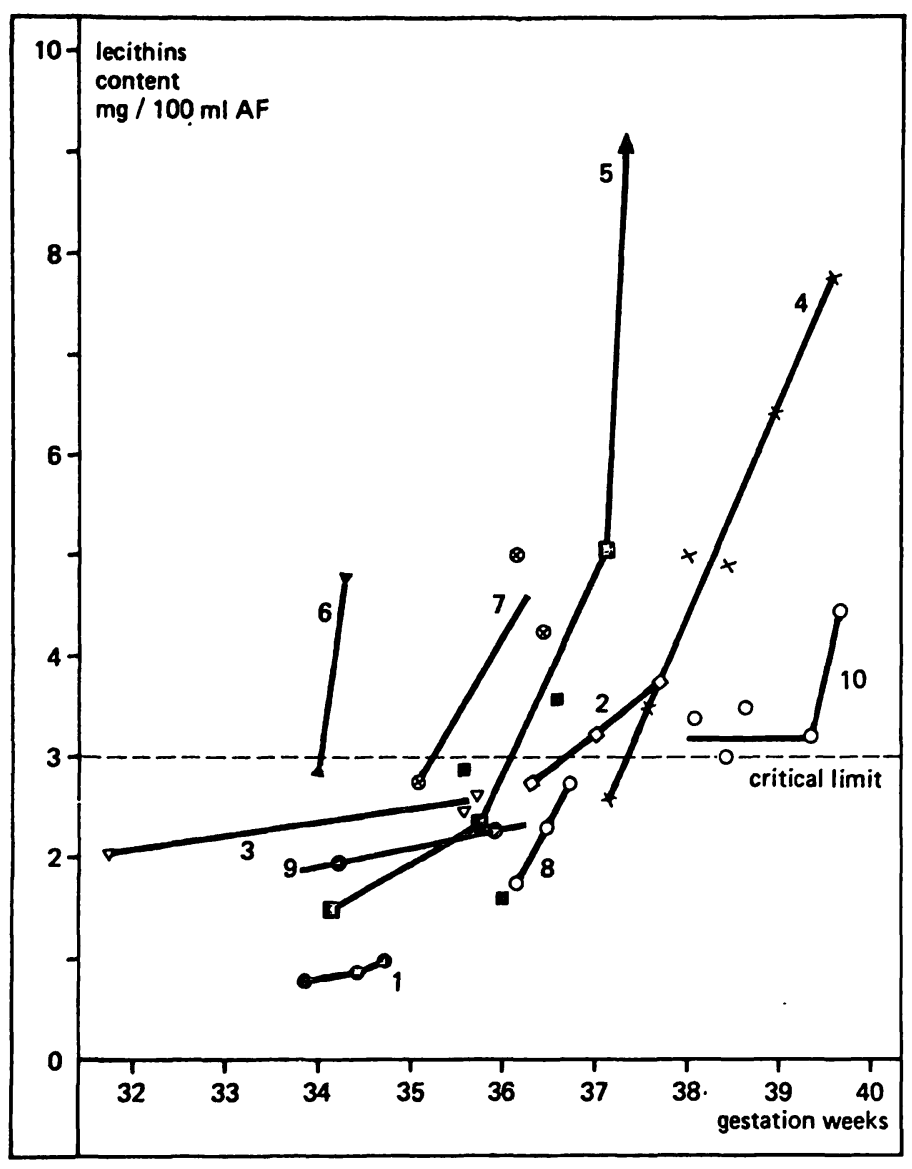

fluid (Tab. I). This method has been applied to more than 400 samples of amniotic fluid from about 360 patients. A small group of patients was used to demonstrate that after early diagnosis of lecithins deficit, delay of labor may allow lung maturation in some cases. When this was not achieved more or less severe symptoms of RDS were observed. A relationship between low lecithins values and dysmaturity was observed. Administration of tocolytic drugs (Th 1165a) did not raise the lecithins content. In conclusion, our procedure makes it possible to recognize respiratory disturbances caused by low lecithins content. derung der Anfärbung der Dünnschichtplatten die wichtigste Neuerung darstellt.

Zur Verminderung des Arbeitsaufwands wird der Schaumtest nach CLEMENTS [2] als screening-Test vorgeschaltet, dessen Anwendbarkeit vorher an 180 Fruchtwasserproben überprüft wurde. Dabei ergab sich, daß dieser Schaumtest als screening-Verfahren für blut- und mekoniumfreie 
Fruchtwasserproben geeignet ist, als Einzeltest, ohne weitere Absicherung der Ergebnisse ist er jedoch nur bedingt empfehlenswert. Nach einem danach erarbeiteten Verfahrensschema (Fig. 3), das die Aussonderung der unter der kritischen Grenze von 3,0 mg Lezithin/100 ml Fruchtwasser (Tab. I) liegenden Proben erlaubt, wurden seit über einem Jahr mehr als 400 Fruchtwasserproben von etwa 360 Patientinnen überprüft.

An einer kleinen Zahl klinischer Beispiele wird gezeigt, daß bei der so möglichen frühzeitigen Erkennung eines Lezithinmangels in einigen Fällen durch Verzögerung der
Geburt der Eintritt der L'úngenreife erreicht werden konnte. Die Fälle, in denen dies nicht gelang, wiesen mehr oder weniger schwere Symptome des RDS auf. Weiterhin zeigt sich ein Zusammenhang zwischen erniedrigten Lezithinwerten und Dysmaturität. Eine Erhöhung der Lezithinwerte durch Gabe von Tokolytika (Th 1165a) ließ sich nicht nachweisen.

Zusammenfassend läßt sich șagen, daß nach unserem Schema die mit einer Lezithinerniedrigung einhergehenden respiratorischen Störungen gut erfaßt werden können.

Schlüsselwörter: Atemnotsyndrom, Fruchtwasser, Lecithin, Schaumtest.

\section{Résumé}

Diagnostic de routine de la maturité pulmonaire foetale

Le présent article expose un procédé qui permet le contrôle de routine de la maturité pulmonaire des grossesses menacées au moyen des déterminations densitométriques des lécithines dans le liquide amniotique avec évaluation programmée. La densitométrie a été améliorée ici en plusieurs points par rapport au procéde décrit antérieurement [7], le changement de décoloration des plaques de couches minces représentant la principale innovation.

Pour réduire le travail, on a intercalé à titre de screeningtest le test écumeux d'après Clements [2] après l'avoir expérimenté sur 180 échantillons de liquide amniotique et avoir constaté qu'il convient comme screening-method pour les échantillons de liquide amniotique dépourvu de sang et de meconium, mais n'est, toutefois, que conditionnellement recommandable comme test particulier sans autre vérification des résultats. Suivant un schéma de procédure élaboré en vertu de ces résultats (fig. 3) et qui permet la particularisation des échantillons situés audessous de la limite critique de 3,0 mg des lécithines $/ 100 \mathrm{ml}$ de liquide amniotique (tab. I), nous avons examiné depuis plus d'un an plus de 400 échantillons de liquide amniotique de 360 patientes environ.

Nous appuyant sur un petit groupe d'exemples cliniques, nous avons constaté qu'en cas d'un dépistage d'une carence des lécithines, rendu possible à temps grâce à cette méthode, la maturité pulmonaire a pu être atteinte dans quelques cas en retardant la naissance. Dans les cas où les résultats ont été négatifs, on a observé des symptômes plus ou moins graves de RDS. On a constaté encore une corrélation entre des valeurs basses des lécithines et la dysmaturité. L'administration de tocolytica (Th 1165a) ne provoque pas une hausse des valeurs des lécithines.

En résumé, on peut affirmer la possibilité d'un bon dépistage - à l'aide de notre schéma - des troubles respiratoires liés à une baisse des lécithines.

Mots-clés: Liquide amniotique, lécithines, respiratory distress syndrom (RDS), test écumeux.

\section{Bibliography}

[1] Bhagwanani, S. G., D. Fahmy, A. C. Turnbull: Bubble stability test compared with lecithin assay in prediction of respiratory distress syndrome. Brit. Med. J. 1 (1973) 697

[2] Clements, J. A., A. C. G. Platzzker, D. F. Tierney, C. J. Hobel, R. K. Creasy, A. J. Margolis, D. W. Thibeault, W. H. Tooley, W. OH: Assessment of the risk of the respiratory-distress syndrome by a rapid test for surfactant in amniotic fluid. New Engl. J. Med. 286 (1972) 1077

[3] Dewhurst, G. J., A. M. Dunham, D. R. Harvey, C. E. Parkinson: Prediction of respiratory-distress syndrome by estimation of surfactant in the amniotic fluid. Lancet I (1973) 1475

[4] Dudenhausen, J. W., G. Kynast, E. Saling: Vergleich der Konzentrationen von Lezithinen im Fruchtwasser und im Trachealsekret. In: DuDEN- hausen, J. W., E. Saling: Perinatale Medizin, Band V. 6. Deutscher Kongreß für Perinatale Medizin, Berlin, November 1973. Thieme, Stuttgart 1974

[5] Fischer, W. M., E. Halberstadt, H. Rüttgeñs, D. Berg: Kardiotokographie. Thieme, Stuttgart 1973

[6] KeUTH, U.: Membransyndrom (Atemnotsyndrom) der Frühgeborenen. Fortschr. Med. 90 (1973) 693

[7] Krnast, G., E. Saling: Rapid specific determination of amniotic fluid lecithins as a test of fetal lung maturity. J. Perinat. Med. 1 (1973) 213

[8] Krnast, G., J. W. Dudenhausen, E. Saling: Determinations of amniotic fluid lecithins in cases of dysmaturity. In preparation.

[9] Liggins, G. G., R. N. Howiz: A controlled trial of antepartum glucocorticoid treatment for prevention 
of the respiratory distress syndrome in premature infants. Pediatrics 50 (1972) 515

[10] Roux, J. F., J. Nakamura, E. Brown: Assessment of fetal maturation by the foam test. Amer. J. Obstet. Gynec. 117 (1973) 280

[11] RÜtTgers, H., U. LORENZ, W. Schütz, J. WinkLer, F. KUBLI: Vergleich der physikalischen und biochemischen Methoden zur antepartualen Reife-
Diagnostik der fetalen Lunge aus dem Fruchtwasser. In: Dudenhausen, J. W., E. Saling: Perinatale Medizin Band V, 6. Deutscher Kongress für Perinatale Medizin, Berlin, November 1973. Thieme, Stuttgart 1974

[12] Saling, E.: Prämaturitäts- und Dysmaturitäts-Präventionsprogramm (PDP-Programm). Z. Geburtsh. Perinat. 176 (1972) 70
Dr. G. Kynast

Prof. Dr. med. E. Saling Unit of Perinatal Medicine Mariendorfer Weg 28-38

D-1000 Berlin 44/Germany 